\section{Effect of Chlorhexidine on Dentin Bond Strength of Two Adhesive Systems after Storage in Different Media}

\author{
Enio Marcos da Silva1, Daniel Hatschbach Glir ${ }^{1}$, Allana Walesca Martins \\ Castanho Gill'1, Allan Fernando Giovanini' ${ }^{1}$, Adilson Yoshio Furuse², Carla \\ Castiglia Gonzaga ${ }^{1}$
}

\author{
'Graduate Program in Dentistry, \\ UP - Universidade Positivo, \\ Curitiba, PR, Brazil \\ ${ }^{2}$ Department of Operative \\ Dentistry, Endodontics and \\ Dental Materials, Bauru Dental \\ School, USP - Universidade de \\ São Paulo, Bauru, SP, Brazil
}

Correspondence: Carla Castiglia Gonzaga, Rua Prof. Pedro Viriato Parigot de Souza, 5300, 81280330, Curitiba, PR, Brasil. Tel: +55-41-3317-3180. e-mail: carlacgonzaga2@gmail.com

\begin{abstract}
The aim of this study was to evaluate the effect of $2 \%$ chlorhexidine (CHX) application during the bonding protocol on microshear bond strength of two adhesive systems, after storage in different media. Seventy-two human molars had their crowns cut in half and embedded in PVC cylinders with acrylic resin. The specimens were randomly divided into experimental groups $(n=12)$ according to the adhesive system (Ambar and Single Bond 2), use of $\mathrm{CHX}$ in the bonding protocol, and time interval (24 $\mathrm{h}$ and 15 days) in the storage media (distilled water, mineral oil and $1 \%$ sodium hypochlorite $-\mathrm{NaOCI}$ ). Adhesive systems were applied in accordance to manufacturers' recommendations, with or without the use of $\mathrm{CHX}$, and resin composite (Z350 XT) cylinders were placed on the hybridized dentin. After photoactivation, the specimens were stored in distilled water, mineral oil and 1\% $\mathrm{NaOCl}$ for $24 \mathrm{~h}$ and 15 days. Microshear bond strength was determined at a crosshead speed of $0.5 \mathrm{~mm} / \mathrm{min}$ until fracture. The bond strength data were analyzed statistically by 4-way ANOVA and Tukey's test $(\alpha=5 \%)$. Use of CHX in the bonding protocol did not cause loss of bond strength in any of the evaluated situations, irrespective of time and storage medium. The storage medium had no influence on bond strength values after 15 days when the bond protocol without $\mathrm{CHX}$ application was used. However, the use of $\mathrm{CHX}$ in the protocol influenced negatively the bond strength values for Single Bond 2 after 15 days storage in distilled water and $1 \% \mathrm{NaOCl}$.
\end{abstract}

Key Words: adhesive systems, hybrid layer degradation, chlorhexidine, bond strength.

\section{Introduction}

The development of adhesive systems has brought great changes in Restorative Dentistry, since the clinical success of a restoration depends on the marginal sealing between the restorative material and cavity preparation margins. However, their use still causes some clinical problems, particularly related to polymerization shrinkage and stress generation at the resin-dentin interface. These stresses severely force the adhesive layer and may lead to gap formation, which may cause marginal microleakage, marginal discoloration, recurrent caries, pain and postoperative sensitivity. Therefore, a bonding procedure that provides good bond strength and clinical longevity is fundamental for successful direct esthetic restorations with resin composites.

However, the literature reports that durability of the bond between dentin and adhesive systems (hybrid layer) may not be that long and stable (1). It has been demonstrated that with contemporary adhesive systems, dentin bonding degradation may occur over time. The degradation of the hybrid layer may occur due to a series of factors, among them: incomplete penetration and infiltration of monomers into the dentinal substrate after, or concomitant with demineralization (2); heterogeneous distribution of monomers throughout the hybrid layer (3); inadequate or insufficient polymerization (4); degradation and hydrolysis of both the resin component and the exposed and non hybridized collagen (1); activation of endogenous matrix metalloproteinases (MMPs) (5), with enzymatic activity able to degrade the type I collagen fibrils in the hybrid layer (6).

Therefore, different approaches have been proposed to improve the bond strength and monomer infiltration into demineralized dentin, in order to reduce the rate of water absorption, and degradation of exposed collagen and resin matrix (1). Among the approaches most frequently described in the literature, the use of MMP inhibitors (7), such as chlorhexidine digluconate ( $\mathrm{CHX}$ ) have been proposed. $\mathrm{CHX}$ is an amphiphilic molecule that binds to various proteins by a cation-chelation mechanism, and may inhibit the catalytic activity of MMPs by binding with $\mathrm{Zn}^{+2}$ or $\mathrm{Ca}^{+2}$. The use of $\mathrm{CHX}$ in the bond protocol after demineralization with phosphoric acid, in order to stabilize the bond interface and prevent bond strength degradation over time has previously been shown (8). Although a relationship between the collagenolytic activity of dentin and role of MMPs in hybrid layer degradation have previously been reported, the exact mechanism of how 
CHX inhibits MMPs still requires further elucidation (9).

The storage medium may simulate the time and conditions to which restorations will be exposed in the mouth, and this is of great value in the evaluation of organic tissue degradation (2). In general, water, artificial saliva and mineral oil are the media most used for storage in in vitro tests for evaluating bond strength degradation over time $(5,10,11)$. Mineral oil may prevent the effects of water, and preserve the bond interface between the tooth and restoration and is generally used as a control storage medium in bond strength evaluations (10). Nevertheless, storage in water has utmost importance for evaluating the bond strength, because humidity has been considered the major limiting factor for the longevity of direct restorations (12).

More aggressive storage media, such as sodium hypochlorite $(\mathrm{NaOCl})$, have been proposed $(13,14)$. Use of $\mathrm{NaOCl}$ has been suggested for the removal of exposed collagen fibers after acid etching, as an alternative to diminish collagen degradation and incomplete adhesive infiltration. Moreover, the removal of organic material may increase the free energy on the etched dentin surface, facilitating its wetting by the adhesive system (15). However, it should be pointed out that when $\mathrm{NaOCl}$ is used as storage medium, degradation is expected to occur at the bond interface (13).

It is therefore clear that the understanding of the mechanisms by which the reduction in bond strength and degradation of the hybrid layer occur in the long term, is mandatory for the development of new techniques and materials that have better properties and longer clinical longevity. The aim of this study was to evaluate the effect of CHX application during the bonding protocol on microshear bond strength of two adhesive systems, after storage for 24 $\mathrm{h}$ and 15 days in different media (distilled water, mineral oil and $1 \% \mathrm{NaOCl}$. The null hypotheses evaluated in the present study were: i) the application of $\mathrm{CHX}$ during the bonding process would not promote reduction in the bond strength values of two adhesive systems after storage for 15 days in different media; and ii) there would be no reduction in bond strength after storage for 15 days in different media (distilled water, mineral oil and $1 \% \mathrm{NaOCl}$ ) for both the evaluated adhesive systems with and without the application of $\mathrm{CHX}$ during the bonding protocol.

\section{Material and Methods}

In this study, 72 freshly extracted healthy human molars were used. Teeth were obtained by protocols that were approved by the institutional ethics review board of the local University (protocol 404.12A). They were stored in distilled water containing $0.5 \%$ chloramine $\mathrm{T}$ at $4{ }^{\circ} \mathrm{C}$, changed weekly until use.
The roots were removed and the crowns were cut in half and embedded with acrylic resin (Jet, Artigos Odontológicos Clássico Ltda, São Paulo, SP, Brazil) in PVC cylinders $(1.2 \mathrm{~cm}$ high and $2.5 \mathrm{~cm}$ in diameter). The exposed surfaces were abraded in a semi-automatic polishing machine (Buehler MetaServ 250, Lake Bluff, IL, USA) using 180 grit silicon carbide abrasive papers under water-cooling until a flat dentin surface was exposed. To standardize the smear layer, the dentin surfaces were abraded under water-cooling with 600 grit silicon carbide abrasive papers for $1 \mathrm{~min}$.

The specimens were then randomly divided into experimental groups ( $n=12$ ), according to the adhesive system, with or without use of chlorhexidine in the bonding process. Two storage time intervals ( $24 \mathrm{~h}$ or 15 days) and three storage media (distilled water, mineral oil or $1 \%$ $\mathrm{NaOCl})$ were evaluated.

The adhesive systems (Ambar, FGM, Joinville, SC, Brazil and Single Bond 2, 3M ESPE, St. Paul, MN, USA) were applied in accordance with the manufacturers' recommendations. In the groups with 2\% CHX application, it was applied with a microbrush, after acid etching and before adhesive application. The adhesive systems, their composition and application manner are described in Table 1.

Transparent cylindrical matrices, with $0.7 \mathrm{~mm}$ internal diameter and $1 \mathrm{~mm}$ high (Tygon tubing, R-3603, SaintGobain Performance Plastics, Maime Lakes, FL, USA) were used to fabricate the microshear bond strength specimens. Their internal volume was filled with a resin composite (Z350 $\mathrm{XT}, 3 \mathrm{M}$ ESPE) and the cylinders were light activated for 20 $s$ with a LED curing unit (Poly Wireless, Kavo, Joinville, SC, Brazil), with a light intensity of $1100 \mathrm{~mW} / \mathrm{cm}^{2}$. The matrices were immediately removed to expose the resin composite cylinders with a bonded area of $0.38 \mathrm{~mm}^{2}$.

The specimens were then stored in one of the three media (distilled water, mineral oil or $1 \% \mathrm{NaOCl}$ ) at $37{ }^{\circ} \mathrm{C}_{\text {, }}$ for two different time periods: $24 \mathrm{~h}$ or 15 days. The storage media were changed on a weekly basis.

After the storage period, microshear bond strength tests were performed with a universal testing machine (DL2000, EMIC, São José dos Pinhais, PR, Brazil), coupled with a load cell of $50 \mathrm{kgf}$, at a crosshead speed of $0.5 \mathrm{~mm} / \mathrm{min}$ until the specimens fractured. Before the tests, the device was aligned to allow the loading loop (steel wire $0.2 \mathrm{~mm}$ diameter) to be placed as close as possible to the bonded interface at the base of the cylinders.

The fractured surfaces of the specimens were examined under a stereoscopic microscope at 57x magnification (SZX9, Olympus, Tokyo, Japan) to determine the mode of failure. Failure modes were classified as predominantly adhesive, mixed and cohesive within dentin or resin.

The data were statistically analyzed by four-way ANOVA (individual factors were adhesive, use of $\mathrm{CHX}$ in 
the bonding protocol, storage medium and storage time) and Tukey's test ( $\alpha=5 \%)$.

\section{Results}

The results for the microshear bond strength test are shown in Table 2. Statistical analysis indicated significant differences for all main factors: adhesive $(p=0.011)$, use of $\mathrm{CHX}$ in the bond protocol $(p=0.011)$, storage medium $(p=0.000)$ and storage time $(p=0.000)$. Regarding the dual interactions, the following interactions were significant: adhesive ${ }^{*} \mathrm{CHX}(\mathrm{p}=0.000)$; adhesive ${ }^{*}$ storage medium ( $p=0.018)$; CHX storage medium ( $p=0.024)$; storage medium*storage time $(p=0.000)$. The interactions adhesive ${ }^{*}$ storage time $(p=0.101)$, and $\mathrm{CHX}^{*}$ time $(p=0.230)$ were not statistically significant. All triple interactions were not statistically significant ( $p>0.05)$, however, the quadruple interaction was statistically significant $(p=0.002)$.

Considering the individual factors, Single Bond 2 presented higher bond strength values compared with Ambar (11.6 $\pm 0.4 \mathrm{MPa}$ and $10.2 \pm 0.4 \mathrm{MPa}$, respectively means \pm standard error). For $\mathrm{CHX}$ in the bonding protocol, the bond strength was higher for the groups in which $\mathrm{CHX}$ s was applied $(10.2 \pm 0.4 \mathrm{MPa}$ and $11.7 \pm 0.4 \mathrm{MPa}$, respectively for the groups without and with CHX application). Regarding the storage medium, specimens stored in mineral oil and distilled water presented higher bond strength values that were statistically similar $(12.8 \pm 0.5 \mathrm{MPa}$ and $11.2 \pm 0.5 \mathrm{MPa} ; \mathrm{p}=0.075$ ) and higher than those of $1 \% \mathrm{NaOCl}$ $(8.9 \pm 0.5 \mathrm{MPa})$. Finally, for storage time, the bond strength values were higher for $24 \mathrm{~h}$ in comparison with 15 days $(13.0 \pm 0.4 \mathrm{MPa}$ and $8.9 \pm 0.4 \mathrm{MPa}$, respectively).

For Single Bond 2, after $24 \mathrm{~h}$ of storage, the use of $\mathrm{CHX}$
Table 2. Means ( \pm S.D.) for the microshear bond strength test

\begin{tabular}{|c|c|c|c|}
\hline \multicolumn{4}{|c|}{ Single Bond 2} \\
\hline $\begin{array}{l}\text { Use of } \\
\text { CHX }\end{array}$ & $\begin{array}{l}\text { Storage } \\
\text { medium }\end{array}$ & $\begin{array}{l}\text { Storage } \\
\text { time }\end{array}$ & $\begin{array}{l}\text { Bond strength } \\
\text { (MPa) }\end{array}$ \\
\hline \multirow{6}{*}{ No } & \multirow{2}{*}{ Distilled water } & $24 \mathrm{~h}$ & $11.4 \pm 3.6^{\text {bcde }}$ \\
\hline & & 15 days & $6.3 \pm 2.5^{\mathrm{ef}}$ \\
\hline & \multirow{2}{*}{ Mineral oil } & $24 \mathrm{~h}$ & $13.7 \pm 3.5^{\mathrm{bcd}}$ \\
\hline & & 15 days & $9,8 \pm 4.0^{\text {cdef }}$ \\
\hline & \multirow{2}{*}{$1 \% \mathrm{NaOCl}$} & $24 \mathrm{~h}$ & $9.9 \pm 4.2^{\text {cdef }}$ \\
\hline & & 15 days & $4.2 \pm 3.9^{f}$ \\
\hline \multirow{6}{*}{ Yes } & \multirow{2}{*}{ Distilled water } & $24 \mathrm{~h}$ & $21.7 \pm 6.7^{\mathrm{a}}$ \\
\hline & & 15 days & $11.1 \pm 3.6$ bcdef \\
\hline & \multirow{2}{*}{ Mineral oil } & $24 \mathrm{~h}$ & $14.8 \pm 2.9 \mathrm{abc}$ \\
\hline & & 15 days & $18.0 \pm 11.3^{a b}$ \\
\hline & \multirow{2}{*}{$1 \% \mathrm{NaOCl}$} & $24 \mathrm{~h}$ & $14.3 \pm 3.2 \mathrm{bcd}$ \\
\hline & & 15 days & $5.3 \pm 3.1$ ef \\
\hline \multicolumn{4}{|c|}{ Ambar } \\
\hline $\begin{array}{l}\text { Use of } \\
\text { CHX }\end{array}$ & $\begin{array}{l}\text { Storage } \\
\text { medium }\end{array}$ & $\begin{array}{l}\text { Storage } \\
\text { time }\end{array}$ & $\begin{array}{l}\text { Bond strength } \\
\text { (MPa) }\end{array}$ \\
\hline \multirow{6}{*}{ No } & \multirow{2}{*}{ Distilled water } & $24 \mathrm{~h}$ & $12.5 \pm 7.6$ bcde \\
\hline & & 15 days & $7.7 \pm 3.6$ cdef \\
\hline & \multirow{2}{*}{ Mineral oil } & $24 \mathrm{~h}$ & $9.6 \pm 7.2^{\text {cdef }}$ \\
\hline & & 15 days & $14.0 \pm 6.0 \mathrm{bcd}$ \\
\hline & \multirow{2}{*}{$1 \% \mathrm{NaOCl}$} & $24 \mathrm{~h}$ & $14.2 \pm 3.7 \mathrm{bcd}$ \\
\hline & & 15 days & $8.6 \pm 4.5^{\text {cdef }}$ \\
\hline \multirow{6}{*}{ Yes } & \multirow{2}{*}{ Distilled water } & $24 \mathrm{~h}$ & $11.2 \pm 5.9^{\text {bcdef }}$ \\
\hline & & 15 days & $6.8 \pm 4.2^{\mathrm{def}}$ \\
\hline & \multirow{2}{*}{ Mineral oil } & $24 \mathrm{~h}$ & $12.7 \pm 5.7^{\text {bcde }}$ \\
\hline & & 15 days & $10.2 \pm 2.8^{\mathrm{bcdef}}$ \\
\hline & \multirow{2}{*}{$1 \% \mathrm{NaOCl}$} & $24 \mathrm{~h}$ & $10.3 \pm 4.0^{\text {bcdef }}$ \\
\hline & & 15 days & $4.1 \pm 1.6^{f}$ \\
\hline
\end{tabular}

Values followed by the same letters are statistically similar ( $p>0.05)$.

Table 1. Composition and application technique of the adhesive systems

\begin{tabular}{|c|c|c|}
\hline Material & Composition & Bonding procedure \\
\hline $\begin{array}{l}\text { Single Bond } 2 \\
\text { (3M ESPE, } \\
\text { St. Paul, MN, USA) }\end{array}$ & $\begin{array}{l}\text { Etchant: 37\% phosphoric acid Adhesive: HEMA, bis-GMA, } \\
\text { DMA's, methacrylate functional Copolymer of polyacrylic } \\
\text { and polyitaconic acids, water, ethanol, photo-initiator }\end{array}$ & $\begin{array}{l}\text { 1. Apply etchant to dentin and wait } 15 \mathrm{~s} \\
\text { 2. Rinse for } 10 \mathrm{~s} \text { * } \\
\text { 3. Blot excess water using absorbent paper until the } \\
\text { surface appears glistening without pooling of water } \\
\text { 4. Apply } 2 \text { consecutive coats of adhesive with gentle } \\
\text { agitation using a fully saturated microbrush } \\
\text { 5. Gently air blow for } 5 \mathrm{~s} \text { to evaporate solvents } \\
\text { 6. Light-cure for } 10 \mathrm{~s}\end{array}$ \\
\hline $\begin{array}{l}\text { Ambar } \\
\text { (FGM, Joinville, } \\
\text { SC, Brazil) }\end{array}$ & $\begin{array}{l}\text { Etchant: } 37 \% \text { phosphoric acid Adhesive: Methacrylate } \\
\text { monomers (UDMA and MDP), photoinitiatiors, co-initiators, } \\
\text { stabilizers, inert silica nanoparticles and ethanol }\end{array}$ & $\begin{array}{l}\text { 1. Apply etchant to dentin and wait } 15 \mathrm{~s} \\
\text { 2. Rinse for } 10 \mathrm{~s} \text { * } \\
\text { 3. Blot excess water using absorbent paper until the } \\
\text { surface appears glistening without pooling of water } \\
\text { 4. Apply two coats vigorously by rubbing the adhesive } \\
\text { for } 20 \mathrm{~s}(10 \mathrm{~s} \text { each) using a fully saturated microbrush } \\
\text { 5. Gently air blow for } 5 \mathrm{~s} \text { to evaporate solvents } \\
\text { 6. Light-cure for } 10 \mathrm{~s}\end{array}$ \\
\hline
\end{tabular}

In the groups where CHX was used, this step was followed by the application of a $2 \% \mathrm{CHX}$ solution with a fully saturated microbrush for $15 \mathrm{~s}$ 
in the bonding protocol presented a statistically significant increase in the bond strength values only for storage in water. For storage in mineral oil and $\mathrm{NaOCl}$, there was no statistical difference in the bond strength values. Whereas for the storage time of 15 days in mineral oil medium there was a statistically significant increase in bond strength. For the distilled water and $\mathrm{NaOCl}$ media, the bond strength values were statistically similar. There was no statistical difference in the bond strength values for Ambar in the groups with and without $\mathrm{CHX}$ application in the bonding protocol, irrespective of time and storage medium.

For the groups without $\mathrm{CHX}$, for both adhesives, there was no significant difference in the bond strength values after 15 days of storage, irrespective of the used medium. For Single Bond 2, in the groups in which CHX was applied, there was a significant reduction in bond strength values after storage for 15 days in distilled water and $\mathrm{NaOCl}$. For storage in mineral oil, the bond strength values remained statistically similar. There was no statistically significant difference in the bond strength values for Ambar after 15 days of storage in the three storage media.

The results of the failure analysis performed after the microshear bond strength test showed that all groups presented predominantly adhesive (between 80 and 92\%) and mixed (between 6 and 12\%) failures. There were between 2 and 8\% cohesive failures in resin.

\section{Discussion}

The first null hypothesis was accepted because the application of $\mathrm{CHX}$ during the bonding protocol did not promote a reduction in the bond strength values of the two adhesive systems after storage for $24 \mathrm{~h}$ and 15 days in different media. In the present study, the use of CHX did not cause loss of bond strength in any of the considered situations, irrespective of time and storage medium.

In the present study, two-step etch-and-rinse adhesives were evaluated. Although the direct comparison between brands is not possible, some differences should be discussed. While Single Bond 2 showed higher bond strength, at the same time the use of $\mathrm{CHX}$ influenced negatively its bond strength values after 15 days storage in distilled water and $1 \% \mathrm{NaOCl}$. Since data were analyzed with factorial ANOVA, the general results in which the use of $\mathrm{CHX}$ in the bonding protocol increased bond strength $(11.7 \pm 0.4$ $\mathrm{MPa}$, as opposed to $10.2 \pm 0.4 \mathrm{MPa}$ when $\mathrm{CHX}$ not applied), it may be assumed that Ambar was more influenced by CHX than Single Bond 2.

It is known that when collagen fibrils remain exposed in the hybrid layer, they may be degraded by the activated MMPs. The literature has shown the occurrence of nanoleakage in the hybrid layer when conventional and self-etching adhesive systems are used, suggesting the exposure of collagen fibrils during the clinical use of adhesive systems in resin composite restorations (16). Over time, degradation of the bond interface may clinically appear as loss of retention of the restoration, or in in vitro studies, as a reduction in bond strength after longer time intervals.

CHX has mainly been used as a disinfectant solution after cavity preparations, and as an irrigant agent in Dentistry. However, the literature indicates that the application of a $\mathrm{CHX}$ solution on dentin surfaces etched with phosphoric acid, promotes maintenance of the bond strength of adhesive systems in the short term both in vitro and in vivo $(7,8,17,18)$. The results of the present study confirm the findings reported in the literature, indicating that $\mathrm{CHX}$ may prevent degradation of the hybrid layer and bond interface over time. Besides presenting a well-known wide antimicrobial spectrum, CHX solutions also have substantivity. Substantivity means that after application the material remains active on the tooth surface for prolonged periods (19), which may add some advantage to the action of $\mathrm{CHX}$ in the long term. In contrast, the use of $\mathrm{CHX}$ pretreatment has shown controversial results and it is not always able to preserve the adhesive interface stability in the long term $(11,17,20)$.

The mechanism by which degradation of the bond interface occurs is not yet completely clear. However, this process may be defined as a complex phenomenon that involves both substrates (dentin and adhesive systems) and is negatively affected by the action of water (hydrolytic degradation) and enzymes present in dentin (enzymatic degradation) (9).

Moreover, it is advisable to test the bond strength in vitro after at least $24 \mathrm{~h}$, to determine whether $\mathrm{CHX}$ is capable of causing any deleterious initial effect, and proceed with tests after longer storage times in order to assess its benefits in the long term. However, there is still scarce information regarding the results of $\mathrm{CHX}$ in the bond protocol in the long term (18). There are still few studies that made evaluations in time intervals longer than 12 months $(7,17)$. Therefore, the prevention of degradation of the hybrid layer and incompletely hybridized collagen fibrils by MMPs is an important question to invest in studies that evaluate the longevity of bond interfaces, because this may be the key to increase the durability of restorations that involve the use of adhesive systems in dentin. In this way, many adhesive systems, modifications in application protocols and MMP inhibitors should be tested in the endeavor to seek more efficient ways of preventing degradation of the hybrid layer by the action of MMPs (18).

The second null hypothesis evaluated, that there would be no reduction in the bond strength after storage for 15 days in different media (distilled water, mineral oil and 
$1 \% \mathrm{NaOCl}$ ) for the two adhesives tested, with and without $\mathrm{CHX}$ application in the bonding protocol was rejected. The results of the present study showed that the storage medium had no influence on bond strength values after 15 days when the bonding protocol without $\mathrm{CHX}$ application was used. However, the use of $\mathrm{CHX}$ led to a reduction in bond strength values for Single Bond 2 after 15 days storage in distilled water and $1 \% \mathrm{NaOCl}$. An interesting finding was the increase in bond strength when mineral oil was used as storage medium for 15 days. In the present study, the immersion in oil was performed as a control storage medium to allow the hybrid layer to remain undisturbed since no or minimum hydrolytic degradation is supposed to occur. Thus, when samples are stored in oil an absence of plasticizing effect is expected. The increase in bond strength could also be related to the well-known increase in the degree of conversion of resin-based materials that occurs over time. This may be explained considering the idea that the polymerization is a continuous chain reaction that takes place even days after the light activation, it could be hypothesized that the adhesive bonding would have some sort of maturation during storage period in mineral oil.

Many studies that evaluate bond strength of the bonded interface use short time intervals of storage, generally 24 $\mathrm{h}$ (21). However, changes in $\mathrm{pH}$, temperature, masticatory loads and chemical attacks occur in the oral cavity and the challenge to the interface by these factors may persist for months or years (22). Although the oral cavity would be the best environment for tests to predict the behavior of restorations, due to the complexity of the factors and diversity of intraoral conditions, in vitro models are also capable of simulating some of the conditions found in the mouth. Moreover, they may be more important for providing information about the fundamental mechanisms of degradation of the bonded interface. Therefore, it is possible to simulate the aging of restorations in vitro, and predict the interactions, longevity and durability of the bonds between the adhesive systems and dentin over time.

One of the methods for evaluating the longevity of the bond interface is its exposure to an aqueous solution of sodium hypochlorite (13). An in vivo analysis of bond degradation between adhesive systems and dentin after exposure to $\mathrm{NaOCl}$ revealed that the collagen fibrils that are not completely infiltrated by adhesive are deproteinized. A $10 \% \mathrm{NaOCl}$ solution, which may act as a deproteinizing agent, has been described as a rapid method for simulating the degradation that occurs in vivo $(13,14)$ by the removal of organic components at bonding interfaces (13). The solution acts on the formation of superoxide radicals, inducing the phenomena of oxidation that break up the peptide chain (14).

Yamauti et al. (14) demonstrated that the use of a 646
$10 \%$ solution of $\mathrm{NaOCl}$ is able to dissolve the hybrid layer of both conventional and self-etching adhesives. These authors showed that there was a reduction in the microtensile bond strength values after a storage period of $5 \mathrm{~h}$. Similar results were obtained by Monticelli et al. (23), indicating that this reduction in bond strength was strongly related to the storage period, since storage in a $\mathrm{NaOCl}$ solution for $1 \mathrm{~h}$ was not sufficient to completely dissolve the hybrid layer. On the other hand, De Munck et al. (13) observed a reduction in bond strength to dentin for a one-step HEMA-free adhesive after storage in a 10\% $\mathrm{NaOCl}$ solution for $1 \mathrm{~h}$. The literature reports that the main effect of bond strength degradation when specimens are immersed in $\mathrm{NaOCl}$ occurs during the first hour of storage (14), and sometimes longer storage times may not result in an additional reduction in bond strength (24).

It must be emphasized that according to De Munck et al. (13) the reduction in bond strength values in microtensile tests after storage in $\mathrm{NaOCl}$ was relatively high, particularly when compared with other artificial aging methodologies, such as thermal cycling, for example. This means that the immersion in $\mathrm{NaOCl}$ may be considered a rigorous method of aging, but one that may be performed in a short period of time.

In the present study, a $1 \% \mathrm{NaOCl}$ solution was used, in a lower concentration than the majority of above mentioned studies (which used 10\% solutions), but for a longer storage time ( 15 days, in comparison with times between 1 and $5 \mathrm{~h}$ mentioned in the studies). This change was made in order to allow the storage time in the different media used in the present study (distilled water, mineral oil and sodium hypochlorite) to be equal, since in the pilot study the authors observed that concentrations such as 5\% and $10 \%$ caused a degradation of both adhesive interface and dental structure that was too intense to allow the microshear evaluations after the 15-day storage.

Finally, it should be pointed out that biodegradation of the bond interface is a complex phenomenon of utmost importance for determining the clinical longevity of restorations made of resin composite. Therefore, further studies are necessary to evaluate the mechanisms involved in this phenomenon, in an endeavor to find solution for diminishing or resolving the problem.

Within the limitations of this study, it can be concluded that the use of CHX in the bonding protocol did not cause decrease of bond strength in any of the situations evaluated, irrespective of time and storage medium; and that the storage medium had no influence on bond strength values after 15 days when the bond protocol without CHX application was used. However, the use of $\mathrm{CHX}$ in the protocol influenced negatively the bond strength for Single Bond 2 after 15 days storage in distilled water and $1 \% \mathrm{NaOCl}$. 


\section{Resumo}

0 objetivo deste trabalho foi avaliar o efeito da aplicação de clorexidina 2\% (CHX) na resistência de união (RU) ao microcisalhamento de dois sistemas adesivos após armazenagem em diferentes meios. Setenta e duas coroas de molares humanos foram cortadas e incluidas em cilindros de PVC. Os espécimes foram distribuídos aleatoriamente nos grupos $(n=12)$, segundo o sistema adesivo (Ambar e Single Bond 2), uso ou não de CHX e o tempo (24 h e 15 dias) e meio de armazenamento (água destilada, óleo mineral e hipoclorito de sódio $1 \%$ - $\mathrm{NaOCI}$ ). Os sistemas adesivos foram aplicados de acordo com as recomendações do fabricante, com e sem o uso de CHX, e cilindros de resina composta (Z350 XT) foram colocados sobre a dentina já hibridizada. Após a fotoativação, os espécimes foram armazenados em um dos três meios (água destilada, óleo mineral e $\mathrm{NaOCl}$ a $1 \%$ ) a $37^{\circ} \mathrm{C}$ por $24 \mathrm{~h} \mathrm{e} 15$ dias. RU foi determinada pelo ensaio de microcisalhamento, com velocidade de $0,5 \mathrm{~mm} / \mathrm{min}$. Os dados foram analisados por ANOVA a quatro fatores e teste de Tukey $(\alpha=5 \%)$. 0 uso da $\mathrm{CHX}$ não provocou perda de RU em nenhuma das situações avaliadas, independentemente do tempo e meio de armazenamento. Não houve influência do meio de armazenamento na RU após 15 dias quando foi utilizado o protocolo adesivo sem a aplicação de CHX. Porém, a utilização de CHX influenciou negativamente os valores de RU para o Single Bond 2 após 15 dias de armazenamento em água destilada e $\mathrm{NaOCl}$ a $1 \%$.

\section{References}

1. Breschi L, Mazzoni A, Ruggeri A, Cadenaro M, Di Lenarda R, De Stefano Dorigo E. Dental adhesion review: aging and stability of the bonded interface. Dent Mater 2008;24:90-101.

2. Hashimoto M, Ohno H, Endo K, Kaga M, Sano H, Oguchi H. The effect of hybrid layer thickness on bond strength: demineralized dentin zone of the hybrid layer. Dent Mater 2000;16:406-411.

3. Eliades G, Vougiouklakis G, Palaghias G. Heterogeneous distribution of single-bottle adhesive monomers in the resin-dentin interdiffusion zone. Dent Mater 2001;17:277-283.

4. Sencer $P$, Wang $Y$, Walker MP, Swafford JR. Molecular structure of acidetched dentin smear layers - in situ study. J Dent Res 2001;80:18021807.

5. Pashley DH, Tay FR, Yiu C, Hashimoto M, Breschi L, Carvalho RM, et al.. Collagen degradation by host-derived enzymes during aging. J Dent Res 2004;83:216-221.

6. Mazzoni A, Pashley DH, Nishitani Y, Breschi L, Mannello F, Tjaderhane $L$, et al.. Reactivation of inactivated endogenous proteolytic activities in phosphoric acid-etched dentine by etch-and-rinse adhesives. Biomaterials 2006;27:4470-4476.

7. Carrilho MR, Carvalho RM, de Goes MF, di Hipolito V, Geraldeli S, Tay $F R$, et al.. Chlorhexidine preserves dentin bond in vitro. J Dent Res 2007;86:90-94.

8. Breschi L, Mazzoni A, Nato F, Carrilho M, Visintini E, Tjaderhane L, et al.. Chlorhexidine stabilizes the adhesive interface: a 2-year in vitro study. Dent Mater 2010;26:320-325.

9. Ricci HA, Sanabe ME, Souza Costa CA, Pashley DH, Hebling J. Chlorhexidine increases the longevity of in vivo resin-dentin bonds.
Eur J Oral Sci 2010:118:411-416.

10. Carrilho MR, Carvalho RM, Tay FR, Yiu C, Pashley DH. Durability of resindentin bonds related to water and oil storage. Am J Dent 2005;18:315319.

11. Montagner AF, Perroni AP, Correa MB, Masotti AS, Pereira-Cenci $T$, Cenci MS. Effect of pre-treatment with chlorhexidine on the retention of restorations: a randomized controlled trial. Braz Dent J 2015;26:234241.

12. Frankenberger $R$, Strobel WO, Lohbauer U, Kramer N, Petschelt A. The effect of six years of water storage on resin composite bonding to human dentin. J Biomed Mater Res B Appl Biomater 2004;69:25-32.

13. De Munck J, Ermis RB, Koshiro K, Inoue S, Ikeda T, Sano $\mathrm{H}$, et al.. NaOCl degradation of a HEMA-free all-in-one adhesive bonded to enamel and dentin following two air-blowing techniques. J Dent 2007;35:74-83.

14. Yamauti $M$, Hashimoto $M$, Sano $H$, Ohno H, Carvalho RM, Kaga $M$, et al.. Degradation of resin-dentin bonds using $\mathrm{NaOCl}$ storage. Dent Mater 2003:19:399-405.

15. Goncalves LS, Consani S, Sinhoreti MA, Schneider LF, Saboia VP. Effect of storage and compressive cycles on the bond strength after collagen removal. Oper Dent 2009;34:681-687.

16. Pioch T, Staehle HJ, Duschner H, Garcia-Godoy F. Nanoleakage at the composite-dentin interface: a review. Am J Dent 2001;14:252-258.

17. Francisconi-dos-Rios LF, Casas-Apayco LC, Calabria MP, Francisconi PA, Borges AF, Wang L. Role of chlorhexidine in bond strength to artificially eroded dentin over time. J Adhes Dent 2015;17:133-139.

18. Moon PC, Weaver J, Brooks CN. Review of matrix metalloproteinases' effect on the hybrid dentin bond layer stability and chlorhexidine clinical use to prevent bond failure. Open Dent J 2010;4:147-152.

19. Souza $M$, Cecchin $D$, Farina $A P$, Leite $C E$, Cruz FF, Pereira $C$ da $C$, et al.. Evaluation of chlorhexidine substantivity on human dentin: a chemical analysis. J Endod 2012;38:1249-1252.

20. Francisconi-dos-Rios LF, Calabria MP, Casas-Apayco LC, Honorio HM, Carrilho MR, Pereira JC, et al.. Chlorhexidine does not improve but preserves bond strength to eroded dentin. Am J Dent 2015;28:28-32.

21. De Munck J, Vargas M, Iracki J, Van Landuyt K, Poitevin A, Lambrechts $P$, et al.. One-day bonding effectiveness of new self-etch adhesives to bur-cut enamel and dentin. Oper Dent 2005;30:39-49.

22. De Munck J, Van Meerbeek B, Satoshi I, Vargas M, Yoshida Y, Armstrong $S$, et al.. Microtensile bond strengths of one- and two-step self-etch adhesives to bur-cut enamel and dentin. Am J Dent 2003;16:414-420.

23. Monticelli $F$, Osorio R, Pisani-Proenca J, Toledano M. Resistance to degradation of resin-dentin bonds using a one-step HEMA-free adhesive. J Dent 2007;35:181-186.

24. Yoshida $E$, Hashimoto $M$, Hori $M$, Kaga $M$, Sano $H$, Oguchi $H$. Deproteinizing effects on resin-tooth bond structures. J Biomed Mater Res B Appl Biomater 2004;68:29-35. 